\title{
PHENOLOGY, MOVEMENT, AND WITHIN-FIELD DISTRIBUTION OF THE GRAPE BERRY MOTH, ENDOPIZA VITEANA (CLEMENS) (LEPIDOPTERA: TORTRICIDAE), IN NEW YORK VINEYARDS
}

\author{
C.J. Hoffman and T.J. DENNEHY \\ Department of Entomology, Cornell University NYSAES, Geneva, New York, USA 14456
}

\begin{abstract}
Can. Ent. 121: 325-335 (1989)

From 1976 to 1986 , the average date of first male pheromone trap catch of grape berry moth was 20 May with an average degree-day (DD) accumulation (base $10^{\circ} \mathrm{C}$ ) of 150.1 $(S E=13.2)$. Fifty percent cumulative trap catch of the first generation of males averaged 334.1 ( $\mathrm{SE}=7.8) \mathrm{DD}$ with an average date of 11 June. Degree-day accumulation was a more accurate method for predicting peak male trap catch than predictions based upon vine phenology and calendar date. Within-field distribution and levels of berry moth infestation were markedly affected by the surrounding habitat. Wooded edges or hedgerows were closely associated with an increase in the level of damage along vineyard borders and higher levels of overall infestation when compared with vineyards without wooded edges. Egg and larval infestation levels in wild hosts (Vitis spp.) were greater than those within adjacent commercial vineyards. Early in the season, male berry moth were trapped in high numbers in wooded areas adjacent to vineyards. After mid-July, males were trapped predominantly within vineyards and few were trapped in wooded edges. Movement of adults from wooded areas into vineyards is not suggested by observed patterns of female oviposition. Females oviposited primarily on wild hosts within the wooded areas and within the adjoining vineyard edges throughout the season.
\end{abstract}

\section{Résumé}

De 1976 à 1986, la date moyenne de première capture au piège à phéromone de la tordeuse de la vigne était le 20 mai, soit en moyenne après l'accumulation de 150,1 DJ (base $\left.10^{\circ} \mathrm{C}\right)(\mathrm{SE}=13,2)$. Le cinquante pourcent de capture cumulative des mâles de première génération s'est produit en moyenne à $334,1(\mathrm{SE}=7,8) \mathrm{DJ}$, à la date moyenne du 11 juin. L'accumulation du temps en DJ s'est avérée une méthode plus exacte de prévision du pic de capture des mâles que les prévisions basées sur la phénologie de la vigne ou sur le calendrier. La distribution intra-champ et le degé d'infestation étaient très affectés par l'habitat. La présence de bordures boisées et de haies était associée à un niveau plus élevé de dommage en périphérie des vignobles, ainsi que des niveaux plus élevés d'infestation d'ensemble, comparé à des vignobles aux bordures non boisées. Les niveaux d'infestation par oeufs ou larves chez des hôtes naturels (Vitis spp.) étaient plus élevés que ceux des vignobles commerciaux adjacents. Tôt en saison, les mâles ont été capturés en nombres élevés dans les boisés adjacents aux vignobles. Après la mi-juillet, les mâles ont été capturés surtout dans les vignobles, peu étant piégés dans les bordures boisées. Le déplacement des adultes des boisés vers les vignes n'apparaît pas comme une possibilité d'après les patrons de pointe des femelles. Les femelles pondaient surtout sur des hôtes naturels dans les boisés et dans la périphérie des vignes durant toute la saison.

\section{Introduction}

The grape berry moth, Endopiza viteana (Clemens), is the most economically important insect pest of commercial grapes in the northeastern United States and the southeastern regions of Canada (Taschenberg 1945; Roberts and Simpson 1982). Larvae feed exclusively upon the flowers and fruit of both wild and cultivated grapes. The berry moth overwinters in pupal diapause (Luciani 1987). The reported number of broods per season ranges from one and a partial second brood (Ingerson 1920) to three full broods (Roberts and Simpson 1982). The long-established tactics employed in New York for management of berry moth rely upon calendar- or vine phenology-based insecticide treatments, generally without prior knowledge of the extent of berry moth pressure in specific vineyards (Taschenberg and Parsons 1960). Levels of berry moth infestation vary dramatically from 
vineyard and from year to year (often found below economically damaging levels) (Sanders and Delong 1921). Sole reliance on prophylactic treatments to control berry moth is due, in part, to the lack of information available to vineyardists with which to assess the severity of vineyard infestations.

We investigated several aspects of berry moth ecology and development in an attempt to understand when and where damage from this pest occurs and to characterize the circumstances that are associated with problematic infestations. Temporal patterns of emergence of the first brood of berry moth, predictions of peak male flight periods, trap catch of male berry moth in vineyards and unmanaged habitats, and the distribution of eggs and larvae in both the wild and cultivated hosts of berry moth were studied. The information from these studies provides a foundation for development of a risk rating system for berry moth and a sampling procedure for the prediction of harvest-level infestation rates (Hoffman and Dennehy 1987; Dennehy et al. 1989).

\section{Materials and Methods}

Pheromone Trapping. From 1976 to 1984, pheromone trapping data were collected from two vineyards in western New York (Chautauqua county) by personnel at the Cornell University Vineyard Laboratory. Two traps were placed within each vineyard (25 and $60 \mathrm{~m}$ from the vineyard edge). Data from these traps were used to evaluate relationships between patterns of adult male emergence (first male and peak flight of first generation) and calendar date, vine phenology, and degree-day accumulation. In 1985 and 1986, four vineyards in western New York, six vineyards in central New York (Yates county), and three vineyards in north-central New York (Wayne county) were monitored. Nine traps were placed in each vineyard in a three by three pattern spaced $30 \mathrm{~m}$ apart beginning $10 \mathrm{~m}$ from the vineyard edge. Three additional traps were placed at the wooded edge of each vineyard (when present) adjacent to the within-vineyard traps. In 1985, a transect of 15 pheromone traps was arranged incorporating three different juxtaposed plant communities (illustrated in Fig. 1). Placement of traps in 1985 and 1986 was designed to characterize berry moth emergence patterns and to detect seasonal movement within and between habitats. To investigate the relationship between peak male trap catch and peak oviposition of the first generation of berry moth, two pheromone traps were placed in each of five vineyards in 1987 and in two vineyards in 1988 in central New York (10 and $40 \mathrm{~m}$ from the vineyard edge). Concurrently, 50-cluster samples of wild grapes growing adjacent to these vineyards were removed weekly and inspected in the laboratory for the presence of berry moth eggs. Pherocon-1C (Zoecon Corp.) traps were used throughout this study. Rubber septa lures containing $100 \mu \mathrm{g}$ of $(Z)-9$-dodecenyl acetate were used from 1976 to 1981 . From 1982 to $1988,10 \mu \mathrm{g}$ of $(Z)$-11-tetradecenyl acetate was added to each septum to increase the efficacy of the synthetic pheromone blend (W.L. Roelofs, Department of Entomology, NYSAES, pers. comm.). Traps were serviced twice weekly throughout each growing season; sticky liners and pheromone lures were replaced at 3-week intervals. Daily maximum-minimum air temperature data in Chautauqua County were obtained from the Cornell University Vineyard Laboratory weather facilities located approximately 1 and $15 \mathrm{~km}$ from the two trapping sites. Degree-day accumulation was based on the sine wave method (Baskerville and Emin 1969).

Direct Sampling. In 1985, beginning on 1 July, 25 grape clusters were removed from each of nine areas (corresponding to the nine trap locations) within two vineyards in central New York (both with adjacent wooded areas, one wooded area containing wild grapes) and inspected using a dissecting microscope in the laboratory for the presence of berry moth eggs and larvae. Within each area, one cluster located between the two top trellis wires was randomly removed from each of 25 vines. Sampling was continued at 3-week intervals until harvest. In 1986, three vineyards in central New York, three vineyards in 


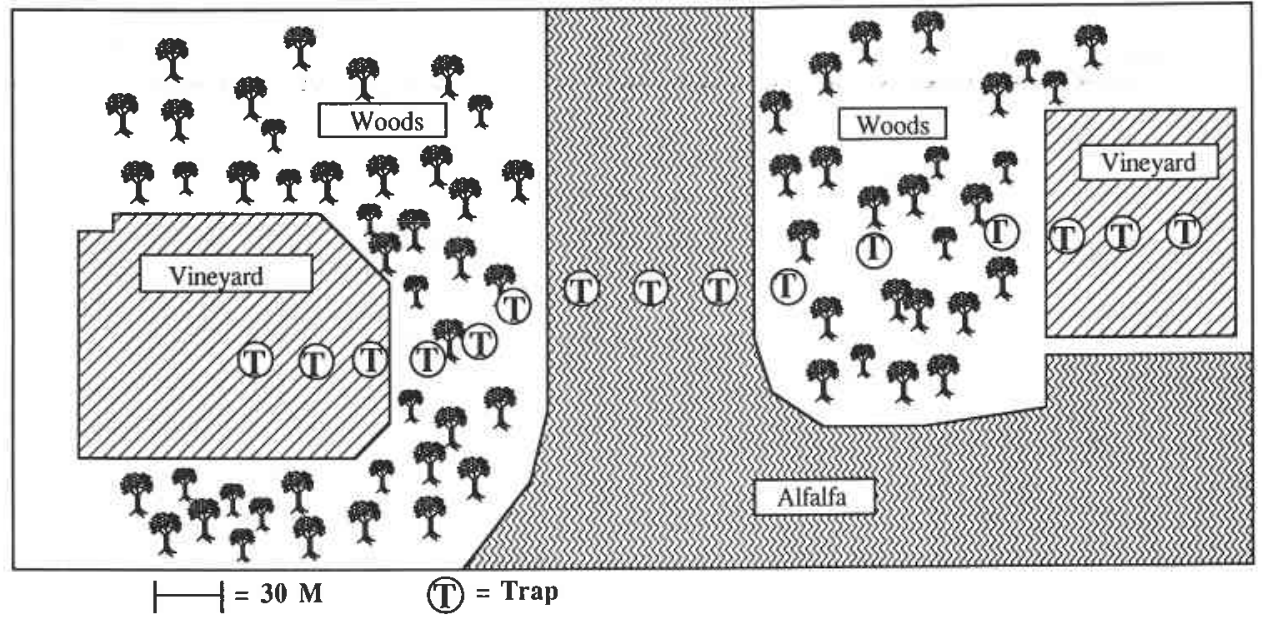

FIG. 1. Placement of a 15-pheromone trap transect for the grape berry moth in three different cover types in Central New York, 1985.

north-central New York, and four vineyards in western New York were sampled in a similar manner beginning on 9 June and thereafter at 3-week intervals until harvest. In 1985 and 1986, three samples of 25 clusters each were removed concurrently from wild grapes adjacent to these vineyards on each sample date. In addition to the vineyards monitored throughout the season, infestation rates at harvest (i.e. one-time evaluations) were determined in five other vineyards in 1985 (one in central and four in western New York) and three vineyards in central New York in 1986.

Statistical analyses were carried out using SAS (General Linear Models Procedure) statistical software package. Infestation rate data were transformed using the arc sine square root of the proportion to account for the heterogeneity in variances.

\section{Results and Discussion}

Phenology. During the years from 1976 to 1986 , the date of the first male moth trapped in western New York ranged from 6 May to 31 May, the average being 20 May. The average degree-day (DD) accumulation from 1 March to first male moth trapped was 150.1 $(\mathrm{SE}=13.2)$ (base $\left.10^{\circ} \mathrm{C}\right)$. Fifty percent cumulative male trap catch of the first generation during 1976-1986 in New York ranged from 30 May to 19 June with the average date being 11 June. The average DD accumulation from 1 March to this date was 334.1 $(\mathrm{SE}=7.8)\left(\right.$ base $\left.10^{\circ} \mathrm{C}\right)$.

Predicting peak oviposition of the first generation is essential for effective control of berry moth. Insecticide treatments are very toxic to berry moth eggs and are targeted at this stage. Therein, peak pheromone trap catch can serve as an advance indicator for berry moth egg deposition and provide growers with a reference point from which to time their treatments. In vineyards surveyed during 1987-1988, we found that the average time period between peak male trap catch and peak egg deposition was 8.29 days $(\mathrm{SE}=1.43$ ) (total $N=7$ vineyards). However, use of pheromone traps for monitoring berry moth has not gained acceptance by grape growers in the northeastern United States. Therefore, we compared the value of alternate predictors: calendar date, DD accumulation, and the phenological stage of the concord grape vine, for estimating $50 \%$ pheromone trap catch (Table 1).

The most reliable method of predicting $50 \%$ cumulative trap catch of berry moth adults (and thus predicting subsequent oviposition) was the accumulation of DD. During the 11-year period evaluated, this method predicted peak trap catch within an average of 
Table 1. Comparison of three methods for predicting peak male trap catch of the first generation of grape berry moth*

\begin{tabular}{|c|c|c|c|c|}
\hline \multirow[b]{2}{*}{ Year } & \multicolumn{3}{|c|}{ Predicted dates of peak trap catch } & \multirow{2}{*}{$\begin{array}{c}\text { Observed } 50 \% \\
\text { trap catch } \|\end{array}$} \\
\hline & Calendar $\dagger$ & 5-days pre-bloom $\neq$ & Degree-day accum $\S$ & \\
\hline 1976 & 11 June (1) & 9 June (1) & 11 June (1) & 10 June \\
\hline 1977 & 11 June (12) & 31 May (1) & 30 May (0) & 30 May \\
\hline 1978 & 11 June (7) & 13 June (5) & 17 June (1) & 18 June \\
\hline 1979 & 11 June (1) & 10 June (0) & 10 June $(0)$ & 10 June \\
\hline 1980 & 11 June (8) & 18 June (1) & 22 June (3) & 19 June \\
\hline 1981 & 11 June (3) & 11 June (3) & 14 June (0) & 14 June \\
\hline 1982 & 11 June (8) & 9 June (6) & 17 June (2) & 15 June \\
\hline 1983 & 11 June (8) & 18 June (1) & 19 June $(0)$ & 19 June \\
\hline 1984 & 11 June (1) & 14 June (4) & 18 June (8) & 10 June \\
\hline 1985 & 11 June (7) & 3 June (1) & 7 June (3) & 4 June \\
\hline 1986 & 11 June (9) & 9 June (7) & 31 May (2) & 2 June \\
\hline
\end{tabular}

*Deviation (in days) from observed $50 \%$ male flight is in parentheses.

†Mean date based on 11 years data.

¥Vine phenology estimates made by R. Pool, Department of Horticultural Sciences, Comell University, NYSAES.

$\S$ Sine wave method, base $10^{\circ} \mathrm{C}$ (Baskerville and Emin 1969).

\|Mean for two vineyards.

1.8 days from the observed date. The next best predictor was vine phenology which predicted peak trap catch within an average of 2.7 days of the observed date. The least accurate method was calendar date which was within an average of 5.6 days of peak male trap catch.

Although we have shown that DD accumulation may be the most accurate method for predicting peak male berry moth trap catch, it is not the most practical. In our studies, meteorological information was obtained from equipment located close to the two trapping locations (1 and $15 \mathrm{~km}$ ). To make predictions based on DD, grape growers would have to use data from regional weather stations. Baker (1980) warns against relying on data from weather stations for predicting phenological events because centralized weather data cannot reflect microclimatic variables affecting the development of an insect. Climatic conditions vary greatly between vineyard locations in New York and factors such as elevation, slope, proximity to lake moderation, and effective air drainage can influence the mesoclimate of vineyard sites. Therefore, for accurate prediction from DD accumulation, weather data should be collected at each location where phenology estimates are required. This is impractical from a growers standpoint.

In contrast with maintaining weather instruments or pheromone traps, observing vine phenology is part of a vineyardists routine. The bloom date of grape vines is very sensitive to seasonal variation in weather. The growth stage of the vine provides the grower with a sensitive reflection of vineyard-by-vineyard variation in heat accumulation. Vine phenology was within 1 day of DD accumulation for predicting peak male trap catch of berry moth. Five days pre-bloom was, on average, 2.7 days from peak pheromone trap catch. Insecticide treatments of first-generation berry moth have traditionally been made at bloom and 10 days post-bloom. Based on peak male emergence occurring 5 days pre-bloom, and based on 8 days between peak male emergence and peak egg deposition, the traditional bloom spray has preceded peak egg deposition by approximately 3 days. Similarly, the 10-day post-bloom spray is estimated to be targeting the first generation approximately 7 days following peak egg deposition.

A possible source of error in these comparisons may come from the service interval of the pheromone traps. In this study, traps were checked every 3 or 4 days and this may, in part, be responsible for a portion of the variability between the methods for predicting 


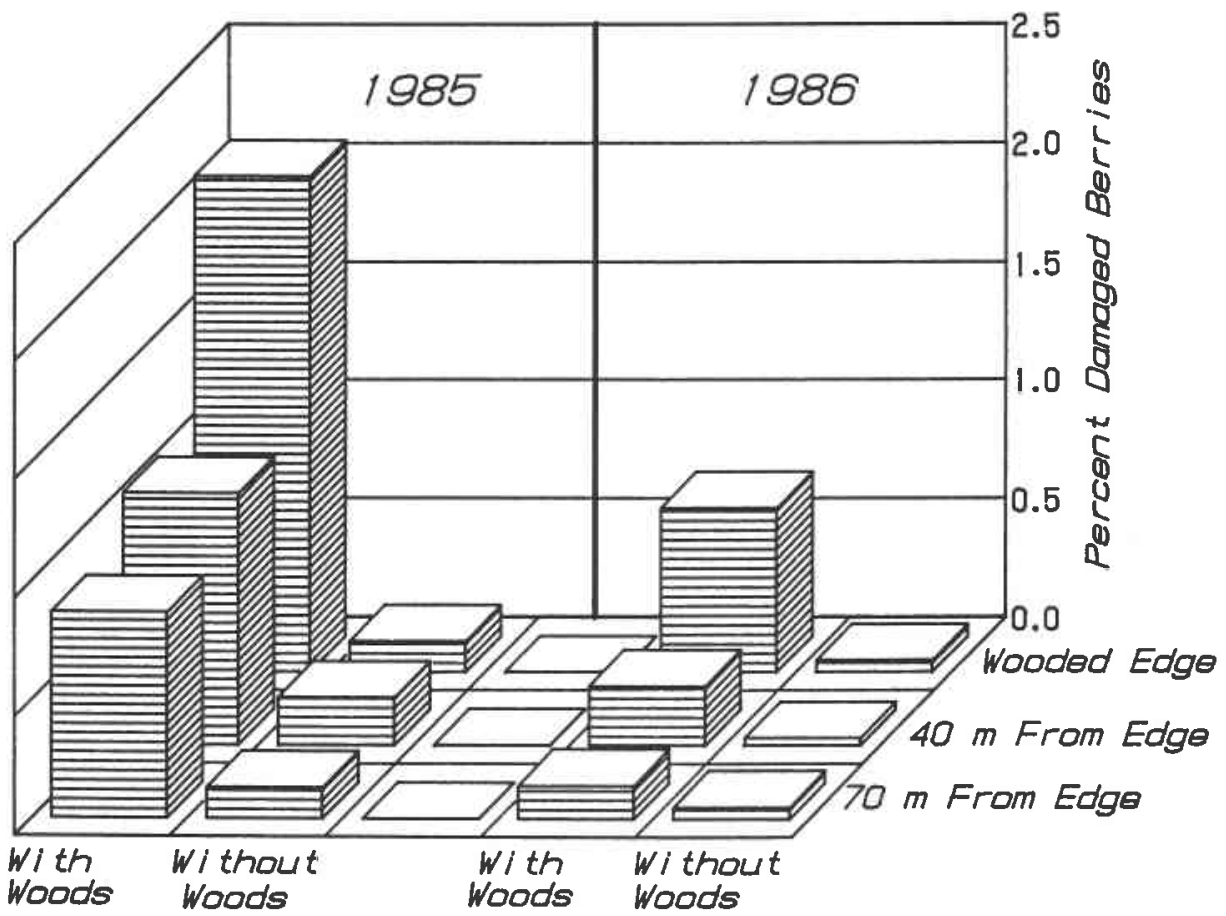

FIG. 2. Distribution of grape berry moth damage at harvest in vineyards with and without wooded edges in 1985 and 1986 (data from Table 2).

$50 \%$ trap catch. However, this source of variability should have acted equally on all three methods for predicting male trap catch.

Temporal and Spatial Dynamics of Fruit Damage by Grape Berry Moth within Vineyards. The type of habitat associated with commercial vineyards had a marked influence upon the level and distribution of berry moth eggs and larvae. Figure 2 illustrates the difference in both the within-field distribution and the level of berry moth infestation in vineyards with, and without, proximal wooded areas. Berry moth distribution in vineyards not adjacent to wooded areas was essentially random and infestation levels were relatively low. However, many vineyards in New York, and most vineyards in certain areas of the state (e.g. locations within the Finger Lakes Area), are bordered on at least one side by wooded areas or hedgerows. The patterns of berry moth infestation in vineyards with such borders are heavily skewed toward the direction of the wooded edge. Strong edge effects and substantially higher rates of infestation were observed in 1985 and 1986 in almost all vineyards bordered by woods (Table 2). Higher rates of infestation were found throughout the growing season on edges adjacent to wooded areas (Fig. 3A), a pattern observed in nearly all vineyards surveyed.

Edge effects of insect oviposition are described often in the literature but are rarely explained (Courtney and Courtney 1982). We hypothesize that the berry moth edge effect observed in New York vineyards results from one or more ecological factors. The areas associated with vineyard edge effects often contain wild Vitis species in abundance. These are the native host plant of berry moth. Infestation rates in wild Vitis growing adjacent to commercial vineyards were extremely high; this suggests a large resident population of berry moth outside the vineyard (Fig. 3B). The continual influx of adults from this wild host may help explain the disproportionate distribution of berry moth in the vineyard edge 
Table 2. Distribution of grape berry moth larval damage at harvest within vineyards estimated by percentage berry infestation (mean $\pm \mathrm{SE}$ )

\begin{tabular}{|c|c|c|c|c|c|}
\hline \multirow[b]{2}{*}{ Year } & \multirow[b]{2}{*}{ Site } & \multirow{2}{*}{$\begin{array}{l}\text { Wooded } \\
\text { edge }\end{array}$} & \multicolumn{3}{|c|}{ Distance $(\mathrm{m})$ from vineyard edge } \\
\hline & & & $0-20$ & $30-50$ & $60-80$ \\
\hline \multirow[t]{7}{*}{1985} & 1 & Yes & $2.55(0.38)$ & $0.85(0.29)$ & $1.09(0.43)$ \\
\hline & *2 & Yes & $4.74(1.61)$ & $1.96(0.25)$ & $1.48(0.18)$ \\
\hline & 3 & Yes & $1.50(0.19)$ & $0.99(0.07)$ & $0.74(0.18)$ \\
\hline & 4 & No & $0.19(0.04)$ & $0.21(0.04)$ & $0.19(0.03)$ \\
\hline & 5 & No & $0.06(0.04)$ & $0.18(0.10)$ & $0.06(0.06)$ \\
\hline & 6 & Yes & $0.41(0.14)$ & $0.40(0.09)$ & $0.16(0.12)$ \\
\hline & 7 & Yes & $1.27(0.63)$ & $1.11(0.32)$ & $0.90(0.14)$ \\
\hline \multirow[t]{15}{*}{1986} & 1 & Yes & $2.53(0.33)$ & $1.10(0.13)$ & $0.53(0.08)$ \\
\hline & $* 2$ & Yes & $1.25(0.35)$ & $0.37(0.07)$ & $0.28(0.07)$ \\
\hline & 4 & No & $0-$ & $0.01(0.01)$ & $0.02(0.02)$ \\
\hline & 8 & Yes & - & $0-$ & $0 \quad-$ \\
\hline & 9 & Yes & - & - & - \\
\hline & 10 & No & - & - & - \\
\hline & 11 & Yes & - & - & - \\
\hline & 12 & No & - & - & - \\
\hline & 13 & Yes & $0 \quad-$ & $0 \quad-$ & $0 \quad-$ \\
\hline & 14 & Yes & $1.03(0.32)$ & $0.26(0.13)$ & $0.14(0.10)$ \\
\hline & 15 & No & $0.21 \quad(0.05)$ & $0.12(0.04)$ & $0.11(0.01)$ \\
\hline & 16 & No & $0.07(0.03)$ & $0.05(0.02)$ & $0.08(0.02)$ \\
\hline & 17 & No & $0.04(0.01)$ & $0 \quad-$ & $0.06(0.01)$ \\
\hline & Mean & Yes $(N=12)$ & $1.27(0.40)$ & $0.59(0.17)$ & $0.44(0.14)$ \\
\hline & & No $(N=8)$ & $0.07(0.03)$ & $0.07(0.03)$ & $0.06(0.02)$ \\
\hline
\end{tabular}

*Without insecticide treatment.

relative to the vineyard proper. However, the structural characteristic of the wooded edge may also influence the distribution of berry moth, as evidenced by results from the vineyard represented by Figure $3 \mathrm{C}$. Here, there was no wild Vitis in the wood edge adjacent to the vineyard, yet the edge effect in oviposition was quite pronounced. High infestation levels in wild hosts adjacent to vineyards suggest the possibility of their use as a trap, or nursery, crop. It is, at the present time, unclear whether the presence of wild Vitis spp. can be exploited in this way. Many vineyards adjacent to wooded areas not containing wild grapes display distribution patterns and levels of infestation similar to those with surrounding wild grapes (see Fig. 3A and C). Though it is clear that wild Vitis is heavily infested by berry moth and serves as an important host adjacent to commercial vineyards, it appears that the wood edge alone is highly correlated with edge effects, irrespective of the presence of wild Vitis spp. Species of wild grape are commonly found growing up the sides of trees along wooded edges. The observed patterns of berry moth oviposition (edge effects) could result from an attraction to the silhouette of wooded edges, much in the same way as the apple maggot, Rhagoletis pomonella (Walsh), is attracted to the silhouette of its host (Moericke et al. 1975). Other factors that could contribute to the observed edge effects include the increased winter survival of berry moth pupae in vineyard edges and adjacent wooded areas due to the insulative effect of snow and/or leaf litter that accumulates in these areas (Green 1962).

Table 2 illustrates within- and between-year differences in berry moth infestation levels. Vineyard-wide infestation levels at harvest ranged from 0 to $2.73 \%$ berry infestation in vineyards with similar chemical treatment regimes. The 1985 season was characterized somewhat above average for berry moth damage in New York vineyards but owing to cool, wet conditions, 1986 was a year of extremely low overall infestations. Vineyards without wooded edges $(N=2)$ averaged $0.15 \%$ berry infestation $(\mathrm{SE}=0.05)$ in 1985 and $0.04 \%$ infestation ( $\mathrm{SE}=0.02)$ in $1986(N=6)$. Vineyards with wooded edges on at least one side 

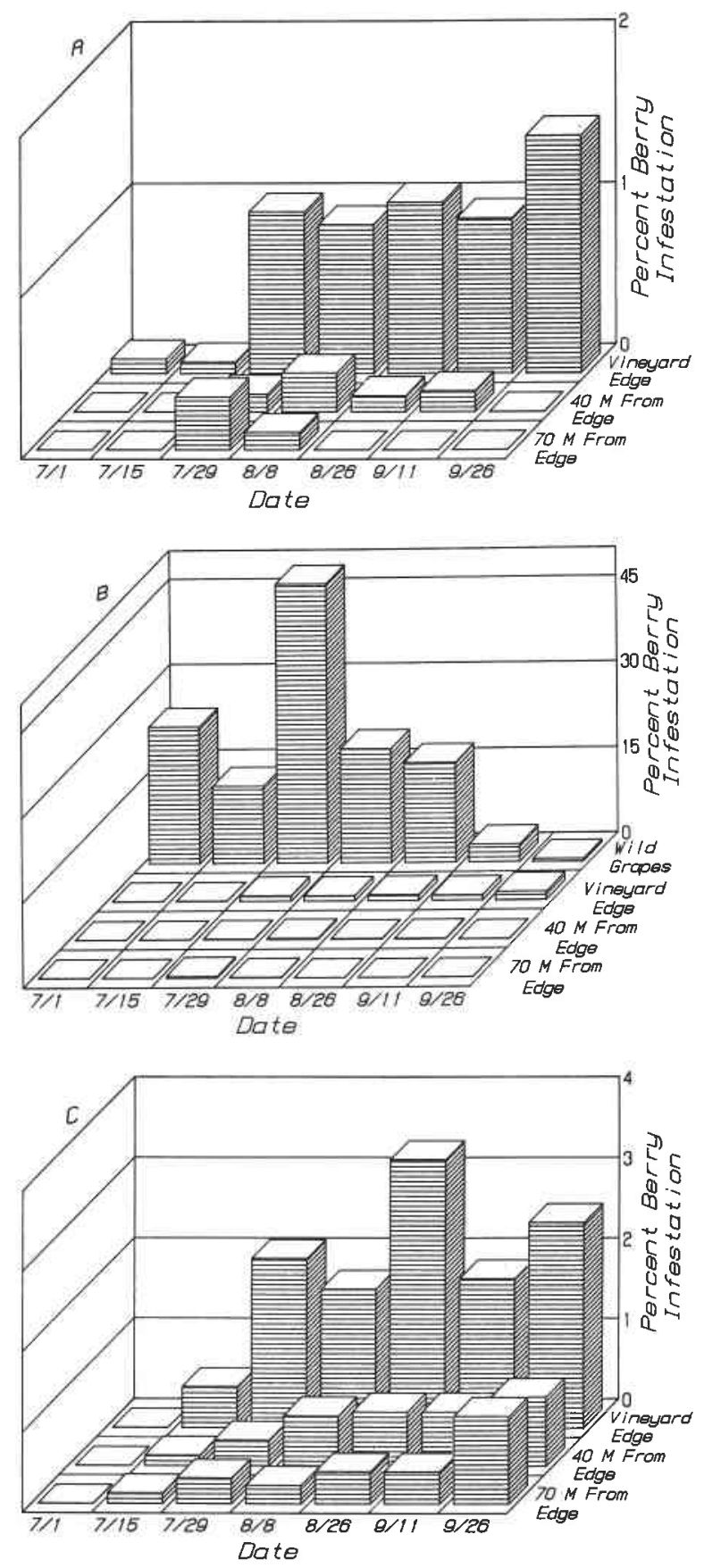

FIG. 3. (A) Distribution of grape berry moth eggs throughout the season in a central New York vineyard bordered on one side by woods containing wild grapes, 1985 . (B) Distribution of grape berry moth eggs throughout the season on wild grapevines and in the adjacent commercial vineyard represented in (A). (C) Distribution of grape berry moth eggs throughout the season in a central New York vineyard bordered on one side by woods not containing wild grapes, 1985 . 


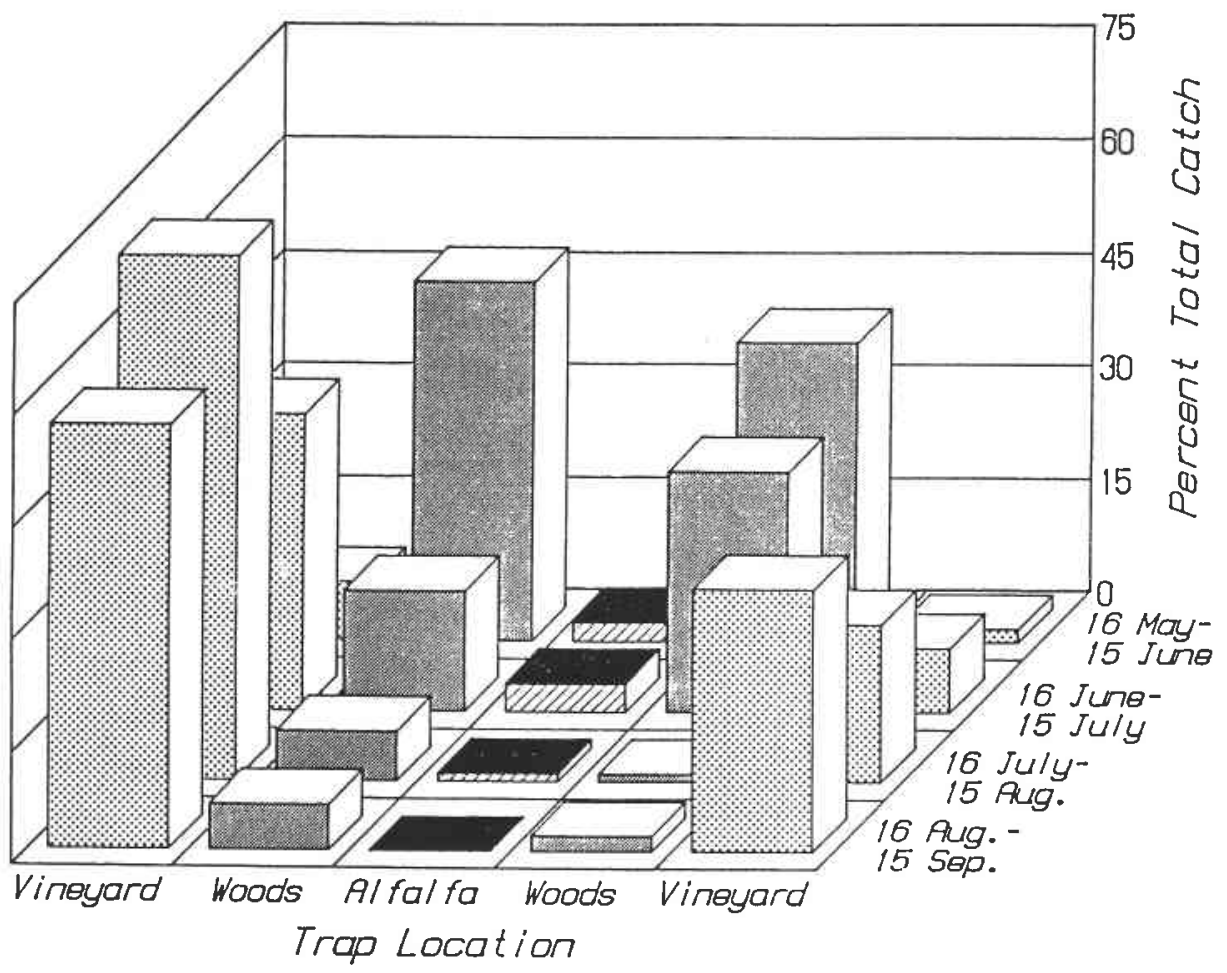

FIG. 4. Percentage of grape berry moths caught in five adjoining cover types throughout the season (see Fig. 1) in central New York, 1985 (total $N=620$ ).

$(N=5)$ averaged a $1.60 \%$ berry infestation $(\mathrm{SE}=0.29)$ in 1985 and a $0.31 \%$ infestation $(\mathrm{SE}=0.19)$ in $1986(N=7)$. The at-harvest threshold stipulated by grape processors in New York State is $2 \%$ damaged berries. Using a general linear models procedure, a significant linear relationship was found between the distance from a wooded edge and the amount of reduction in berry moth damage $(p=0.014)$. In addition, differences in infestation rates in vineyards with wooded edges versus vineyards without wooded edges in both 1985 and 1986 were also significant $(p=0.005)$. Vineyards adjacent to wooded areas are at statistically greater risk of receiving damaging levels of berry moth and management strategies should be tailored to reflect this increased level of risk (Dennehy et al. 1989).

Temporal and Spatial Dynamics of Berry Moth Pheromone Trap Catch in Vineyards and Adjacent Habitats. The use of pheromone traps in and around vineyards was designed to characterize movements of berry moth that might result in the observed edge effects. Results from the 1985 transect of pheromone traps situated in vineyard and non-vineyard habitats (Fig. 1) revealed similar dramatic shifts in the proportion of males caught in the wooded area traps versus traps within the adjacent vineyards (Fig. 4). During the early season, adult males were trapped almost exclusively in wooded areas. By mid-July, there were few males trapped in the wooded habitat. Significant numbers were caught in the vineyard traps during the rest of the season. Few berry moth were trapped in the alfalfa field even though traps were located $2 \mathrm{~m}$ from the wooded edges (Fig. 1) and $4 \mathrm{~m}$ from wooded edge traps (which caught high numbers of adults). The low levels of berry moth trapped in alfalfa suggest a strong preference for vineyard and/or wooded habitats.

Evaluation of pheromone trap catch in numerous vineyards and adjacent wooded areas corroborated the transect findings. In 1985 and 1986, greater proportions of berry moth 


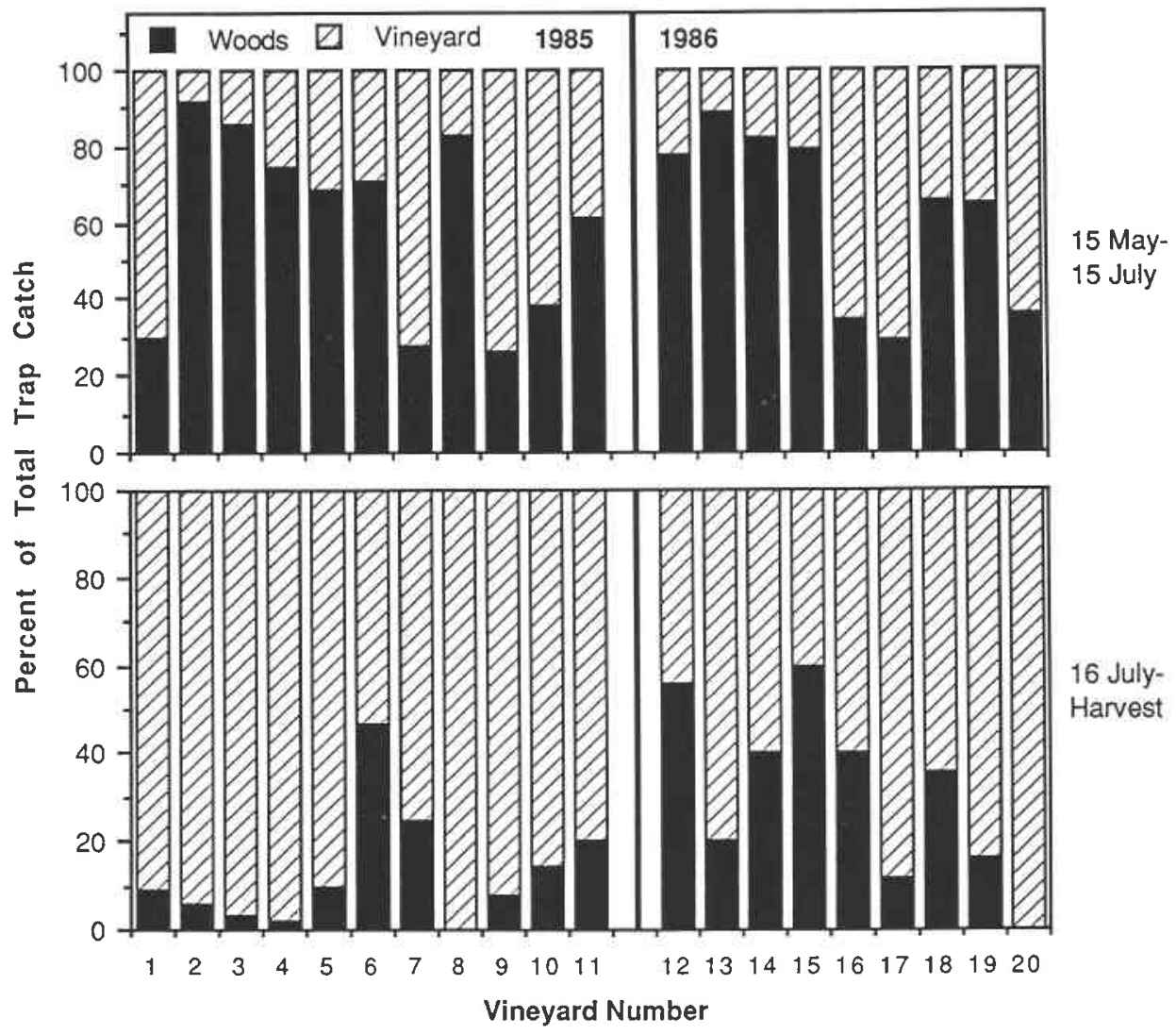

FIG. 5. Percentage of grape berry moths caught in pheromone traps in wooded areas versus moths caught within adjacent vineyards from 15 May to 15 July and from 16 July to harvest (late September) in 1985 and 1986.

males were captured in traps located in wooded areas during the early season (from emergence until mid-July) than during mid and late season (late July until the end of September) (Fig. 5).

The recorded pattern of trap catch of males indicates a directed movement of berry moth adults (male and female) from wooded edges into vineyards. These data provided a convenient explanation for the observed edge effects. However, the spatial distribution of fruit damage throughout the season (Fig. 3A-C) (which results from female activity) does not support the suggestion of directed movement of berry moth away from wooded edges during mid-season. At locations with intermediate and high densities of damaged fruit, the distribution of berry moth eggs and larvae is strongly skewed toward the vineyard edges and adjacent wild grapes. This effect persisted throughout the season (through the second and third generation of berry moth). In other words, high numbers of berry moth eggs were deposited along the wooded edges at times when trap catch in those areas had fallen to negligible levels. Knight and Croft (1987) described the competitive influence of caged female moths, Argyrotaenia citrana (Fernald), on pheromone trap efficiency. We hypothesize that the reduction in pheromone trap catch in wooded areas after mid-July results from competitive effects of relatively high densities of berry moth females in the wooded habitat. In this scenario, the synthetic pheromone lure is ineffective for attracting male berry moth in areas where high densities of females reside. Plausible alternative 
hypotheses for explaining the observed decrease in trap catch in wooded edges would require males to be departing from the habitat where oviposition activity was highest (wooded areas and vineyard edges).

Current tactics for the management of grape berry moth in New York generally do not differ from recommendations made 25 years ago. Insecticide applications, based on calendar date or vine phenology, are often made with little regard for actual levels of infestation or for the potential of incurring economically damaging levels of berry moth at harvest. We have shown that vine phenology is a reliable predictor of male flight of berry moth and subsequent egg deposition. These data can be used to improve the timing of insecticide treatment targeted at this generation. We have also shown that the presence of wooded edges has a marked effect upon both the level and the within-field distribution of berry moth in vineyards. Vineyards adjacent to wooded areas are at greater risk of incurring damaging levels of berry moth and should be managed differently than those without wooded edges. The observed edge effect of berry moth damage in vineyards adjacent to wooded areas suggests the use of space-limited treatment as an option for berry moth control. Data describing the distribution and level of berry moth damage in vineyards is currently being incorporated into a sampling procedure and a system for basing insecticide treatment on risk of berry moth damage rather than on prophylaxis (Dennehy et al. 1989).

\section{Acknowledgments}

The authors thank E.F. Taschenberg and T. Taft of the Cornell University Vineyard Laboratory, Fredonia, NY, for providing trapping data from the period 1976-1984, C. Cummings and C. Brandt for assistance with field and laboratory investigations, and the many grape growers who allowed these studies to be conducted in their vineyards. We thank J. Nyrop, J. Sanderson, and M. Tauber for critical review of this manuscript and G. Rubin for statistical consultation. This work was supported, in part, by grants from the New York State Wine/Grape Foundation, the Andrew Mellon Foundation, and the Grace Griswold Fund.

\section{References}

Baker, C.R.B. 1980. Some problems in using meteorological data to forecast the timing of insect life cycles. EPPO Bull. 10: 83-91.

Baskerville, G.L., and P. Emin. 1969. Rapid estimation of heat unit accumulation from maximum and minimum temperatures. Ecol. 50: 514-517.

Courtney, S.P., and S. Courtney. 1982. The 'edge effect' in butterfly oviposition: causality in Anthocharis cardamines and related species. Ecol. Ent. 7: 131-137.

Dennehy, T.J., C.J. Hoffman, J.P. Nyrop, and M.C. Saunders. 1989. Development of low spray, biological, and pheromone approaches for control of grape berry moth, Endopiza viteana, Clemens, in the eastern United states. In Monitoring and Integrated Pest Management of Arthropod Pests of Small Fruit. Intercept, London. In press.

Green, G.W. 1962. Low winter temperatures and the European pine shoot moth, Thyacionia buoliana (Schiff.), in Ontario. Can. Ent. 94: 314-336.

Hoffman, C.J., and T.J. Dennehy. 1987. Assessing the risk of grape berry moth damage in New York vineyards. New York's Food Life Sci. Bull. 120. 4 pp.

Ingerson, H.G. 1920. Life history of the grape berry moth in northern Ohio. U.S.D.A. Bull. 911.42 pp.

Knight, A.L., and B.A. Croft. 1987. Temporal patterns of competition between a pheromone trap and caged female moths for males of Argyrotaenia citrana (Lepidoptera: Tortricidae) in a semienclosed courtyard. Environ. Ent. 16: 1185-1192.

Luciani, M.A. 1987. The biology of the grape berry moth, Endopiza viteana, Clemens (Lepidoptera: Tortricidae) in southern Ontario. M. Sc. thesis, University of Guelph, Guelph, Ont., Canada. 84 pp.

Moericke, V., R.J. Prokopy, S. Berlocher, and G.L. Bush. 1975. Visual stimuli eliciting attraction of Rhagoletis pomonella (Diptera: Tephritidae) flies to trees. Ent. exp. Appl. 18: 497-507. 
Roberts, W.P., and C.M. Simpson. 1982. Pest management program for grapes series: Monitoring and predicting spray dates for the grape berry moth on the Niagara Peninsula. OMAF Agdex 212/632.

Sanders, J.G., and D.M. Delong. 1921. Factors determining local infestations of the grape berry moth. J. econ. Ent. 14: 488-490.

Taschenberg, E.F. 1945. The biology and control of the grape berry moth, Polychrosis viteana (Clemens). Ph.D. thesis, Cornell University, Ithaca, New York. 232 pp.

Taschenberg, E.F., and G.M. Parsons. 1960. Performance of Sevin against grape berry moth. J. econ. Ent. 53: $856-859$.

(Date received: 14 April 1988; date accepted: 13 December 1988) 